\title{
TINJAUAN PELAKSANAAN RUJUKAN OLEH BIDAN PADA IBUBERSALIN YANG MENGALAMI KOMPLIKASI DI RUMAH SAKITSINGAPARNA MEDIKA CITRAUTAMA KABUPATEN TASIKMALAYA PERIODE BULAN MARET-APRIL TAHUN 2017
}

\author{
Saropah $^{1}$, Widya Maya Ningrum ${ }^{2}$
}

\section{A. ABSTRAK}

Kematian ibu di Rumah Sakit Singaparna Medika Citrautama tahun 2016 sebanyak 18 orang, diantaranya 3 meninggal di ruang Ponek. Hasil studi pendahuluan didapatkan 6 bidan yang melakukan rujukan pada ibu bersalin, dari 6 bidan hanya 2 bidan yang melakukan penanganan pra rujukan sesuai dengan SOP dan melakukan penerapan kelengkapan rujukan sesuai dengan SOP.

Penelitian ini bersifat kuantitatif dengan metode deskriptif, populasi penelitian adalah bidan yang melakukan rujukan pada ibu bersalin yang mengalami komplikasi. Sampelnya sebanyak 33 bidan, diperoleh dengan teknik purposif sampling. Data diperoleh menggunakan daftar checklist dianalisis secara univariat.

Hasil penelitian menunjukan bahwa gambaran penanganan pra rujukan oleh bidan pada ibu bersalin yang mengalami komplikasi sebagaian besar dilakukan sesuai dengan SOP dan untuk penerapan kelengkapan rujukannya sebagian besar tidak dilaksanakan sesuai dengan SOP.

\section{Kata kunci : Gambaran Rujukan, komplikasi pada ibu bersalin yang mengalami komplikasi, penerapan kelengkapan rujukan}

\section{B. PENDAHULUAN}

Menurut Survey Demografi Kesehatan Indonesia (SDKI, 2012) AKI di Indonesia pada tahun 2007 sebesar 228 per 100.000 kelahiran hidup, mengalami peningkatan bila dibandingkan dengan AKI pada tahun 2012 sebesar 359 per 100.000 kelahiran hidup. Sehingga masih jauh dari target Milenium Development Goals (MDGs) 2015, yaitu untuk AKI 102 per 100.000 kelahiran hidup. (Kemenkes RI, 2010) Sehubungan dengan tidak tercapainya target MDGs menurut sekertariat pembangunan sektor kesehatan pasca tahun 2015 PBB telah merubah arah dan tujuan pembangunan global dari MDGs 2015 menjadi Sutainable Development Goals (SDGs) hingga Tahun 2030 yaitu untuk AKI harus mencapai dibawah 70/100.000 Kelahiran Hidup, sehingga diperlukan berbagai upaya untuk pencapaian target.

Menurut profil kesehatan Jawa Barat (2012) jumlah kematian ibu sebanyak $818 \quad(87,99 / 100.000$ kelahiran hidup), penyebab kematian ini dibedakan menjadi penyebab langsung dan penyebab tidak langsung. Penyebab langsung diklasifikasikan menjadi perdarahan $(58,79 \%)$, infeksi $(9,62)$, eklamsia $(13,60 \%)$ dan lain-lain $(17,99 \%$ s). Pada umumnya kematian ibu di Jawa Barat terjadi pada saat melahirkan $(60 \%)$, waktu nifas $(30,43 \%)$ dan waktu hamil $(8,70 \%)$.

Menurut Dinas Kesehatan Kabupaten Tasikmalaya, kematian ibu di Jawa Barat tahun 2016 sampai dengan bulan September yaitu mencapai 45 orang, mengalami penurunan jika dibandingkan dengan kematian ibu di kabupaten 
Tasikmalaya yaitu sebanyak 55 orang. Sebesar $20 \%$ dari persalinan diprediksi akan mengalami komplikasi. Komplikasi yang tidak tertangani akan menyebabkan kematian. Sebagian besar komplikasi dapat dicegah dan ditangani apabila komplikasi terjadi, tenaga kesehatan dapat memberikan pertolongan pertama dan melakukan tindakan stabilisasi pasien sebelum melakukan rujukan, sehingga penanganan pra rujukan pada ibu bersalin yang mengalami koplikasi harus dipertimbangkan sebagai komponen penting dari sistem kesehatan secara keseluruhan, dengan adanya sistem penanganan pra rujukan diharapkan dapat meningkatkan pelayanan kesehatan yang lebih cepat dan tepat, oleh karena itu kelancaran rujukan dapat menjadi faktor yang menentukan untuk menurunkan angka kematian ibu (Kemenkes RI, 2016).

Untuk kelancaran rujukan ada beberapa hal penting yang harus dipersiapkan, yaitu diantaranya 1) Alat: Bawa perlengkapan dan bahan-bahan yang sesuai dengan kebutuhan. 2) Surat: Memberikan surat ketempat rujukan. Surat ini harus memberikan informasi tentang ibu dan bayi, cantunmkan alasan rujukan dan uraikan hasil asuhan yang telah diberikan. Sertakan partograf yang dipakai untuk membuat keputusan klinik. 3) Obat: Membawa obat-obatan esensial sesuai kebutuhan pada saat merujuk ibu ke fasilitas rujukan (Badriah dkk 2012)

Berdasarkan catatan rekam medik di RS SMC Kabupaten Tasikmalaya tahun 2016 kasus rujukan sebanyak 1.063 orang terdiri dari 326 orang ibu hamil, 521 orang ibu bersalin dan 216 ibu nifas. Jumlah kematian ibu di Rumah Sakit Singaparna Medika Citrautama sebanyak 18 orang. Sedangkan pada bulan Januari tahun 2017 jumlah rujukan pada ibu bersalin sebanyak 194 orang, diantaranya dengan kasus PEB $20 \%$, KPD $4 \%$, fetal distress $10 \%$, perpanjangan kala 1 fase laten $32 \%$, perpanjangan kala 1 fase aktif $22 \%$, dan inersia uteri $12 \%$.

Berdasarkan hasil studi pendahuluan yang dilaksanakan pada hari senin tanggal 20 Februari tahun 2017 di Rumah sakit Singaparna Medika Citra Utama didapatkan 6 orang bidan yang melakukan rujukan pada ibu bersalin yang mengalami komplikasi diantaranya: 2 ibu bersalin yang mengalami komplikasi persalinan lama dan $4 \mathrm{ibu}$ bersalin yang mengalami komplikasi KPD. Dari 6 orang ibu bersalin tersebut semuanya datang dengan keadaan lemah dan hanya 1 orang bidan yang melakukan penanganan pra rujukan sesuai dengan komplikasi pada ibu bersalin dan dilihat dari kelengkapan rujukannya sudah lengkap atau sesuai dengan SOP yang telah ditentukan. dan 5 orang bidan tidak melakukan penanganan pra rujukan sesuai dengan komplikasi pada ibu bersalin atau tidak sesuai dengan SOP yang telah ditentukan METODE PENELITIAN

Metode yang digunakan dalam penelitian ini adalah metode deskriptif dengan pendekatan studi kasus, yang bertujuan untuk menggambarkan fenomena mengenai tinjauan pelaksanaan rujukan oleh bidan pada ibu bersalin yang mengalami komplikasi di Rumah Sakit Singaparna Medika Citrautama periode Maret-April tahun 2017.

Sampel dalam penelitian ini adalah bidan yang melakukan rujukan pada ibu bersalin yang mengalami komplikasi yang sesuai dengan kriteria yaitu sebanyak 33 bidan. Sampel diperoleh dengan menggunakan teknik accidental sampling.

\section{B. HASIL PENELITIAN}

\section{Karakteristik Responden}

Penelitian ini dilaksanakan di ruang IGD Ponek Rumah Sakit Singaparna Medika Citra Utama yang dilakukan pada bulan Maret- April Tahun 2017. Bidan yang 
bertugas di ruang IGD Ponek berjumlah 28 orang.

\section{tabel 5.2}

Karakteristik bidan yang merujuk pada ibu bersalin yang mengalami komplikasi

ke Rumah Sakit Singaparna Medika

Citra Utama Kabupaten Tasikmalaya Periode Bulan Maret - April Tahun 2017

\begin{tabular}{|c|c|c|c|}
\hline Karakteristik & Kategori & Jumlah & $\begin{array}{c}\text { Persentase } \\
(\%)\end{array}$ \\
\hline Umur & 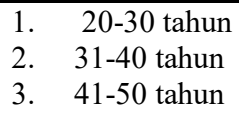 & $\begin{array}{c}17 \\
15 \\
1\end{array}$ & $\begin{array}{r}51,5 \\
45,5 \\
3,0\end{array}$ \\
\hline Pendidikan & $\begin{array}{ll}\text { 1. } & \text { DIII } \\
\text { 2. } & \text { Kebidanan } \\
& \text { DIV } \\
& \text { kebidanan } \\
\end{array}$ & $\begin{array}{c}28 \\
5\end{array}$ & $\begin{array}{l}84,85 \\
15,15\end{array}$ \\
\hline Pelatihan & $\begin{array}{ll}\text { 1. } & \mathrm{APN} \\
\text { 2. } & \mathrm{APN}+\mathrm{PPGD} \\
& \mathrm{ON}\end{array}$ & $\begin{array}{c}30 \\
3\end{array}$ & $90,9 \quad 9,1$ \\
\hline Jumlah & & 33 & 100 \\
\hline
\end{tabular}

Berdasarkan tabel 5.2 didapatkan karakteristik bidan yang melakukan rujukan pada ibu bersalin yang mengalami komplikasi yang sesuai dengan kriteria berdarasarkan umur mayoritas berumur antara 20-30 tahun, yaitu sebanyak 17 bidan (51,5\%). Berdasarkan pendidikan didapatkan 28 bidan $(84,85 \%)$ sebagian besar berpendidikan DIII kebidanan dan pelatihan yang diikuti diantaranya ada yang sudah mengikuti pelatihan APN diantaranya sebanyak $30 \quad(90,9 \%)$ dan yang sudah mengikuti pelatihanAPN+PPGDON sebanyak 3 bidan $(9,1 \%)$.
Tabel 5.3

Distribusi frekuensi rujukan pada ibu bersalin yang mengalami komplikasi yang sesuai dengan kriteriadi Rumah Sakit Singaparna Medika Citra tama Periode Bulan Maret - April Tahun 2017

\begin{tabular}{lcc}
\hline \multicolumn{1}{c}{ Kategori } & Jumlah & $\begin{array}{c}\text { Persentase } \\
(\mathbf{\%})\end{array}$ \\
\hline Gawat janin & 3 & 9,1 \\
\hline $\begin{array}{l}\text { Ketuban pecah } \\
\text { dini }\end{array}$ & 7 & 21,2 \\
\hline $\begin{array}{l}\text { Inersia uteri } \\
\text { Ketuban } \\
\text { bercampur } \\
\text { meconium }\end{array}$ & 19 & 57,6 \\
$\begin{array}{l}\text { Persalinan lama } \\
\begin{array}{l}\text { Retensio } \\
\text { plasenta }\end{array}\end{array}$ & 1 & 3,0 \\
\hline \multicolumn{1}{c}{ Jumlah } & $\mathbf{3 3}$ & $\mathbf{1 0 0}$ \\
\hline
\end{tabular}

Berdasarkan tabel 5.3. tersebut dapat diketahui bahwa gambaran rujukan pada ibu bersalin dengan komplikasi yang sesuai dengan kriteria mayoritas bidan melakukan rujukan pada ibu bersalin dengan komplikasi Inersia Uteri yaitu sebanyak 19 komplikasi $(57,6 \%)$.

Tabel 5.4

Distribusi frekuensi penanganan pra rujukan pada ibu bersalin yang mengalami komplikasi di Rumah Sakit Singaparna Medika Citra Utama

Periode Bulan Maret - April Tahun 2017

\begin{tabular}{lcc}
\hline $\begin{array}{l}\text { Penanganan } \\
\text { pra rujukan }\end{array}$ & Jumlah & $\begin{array}{l}\text { Persentse } \\
(\%)\end{array}$ \\
\hline Penangana & 20 & 60,6 \\
pra & & \\
rujukan & & \\
sesuai & & \\
dengan & & \\
\hline
\end{tabular}




\begin{tabular}{|c|c|c|}
\hline SOP & & \\
\hline $\begin{array}{l}\text { Penanganan } \\
\text { pra }\end{array}$ & 13 & 39,4 \\
\hline $\begin{array}{l}\text { Rujukan } \\
\text { tidak sesuai } \\
\text { dengan } \\
\text { SOP }\end{array}$ & & \\
\hline Jumlah & 33 & 100 \\
\hline
\end{tabular}

Berdasarkan tabel 5.4 tersebut dapat diketahui bahwa distribusi frekuensi responden yang melakukan penanganan pra rujukan pada ibu bersalin yang mengalami komplikasi di Rumah Sakit Singaarna Medika Citra Utama Periode Bulan Maret - April Tahun 2017 mayoritas bidan melakukan penanganan pra rujukan pada ibu bersalin yang mengalami komplikasi yaitu sebanyak 20 orang ( $60,6 \%)$ dan yang tidak melakukan penanganan pra rujukan yaitu 13 orang $(39,4 \%)$.

Berdasarkan tabel 5.5 tersebut dapat diketahui bahwa penerapan kelengkapan rujukan oleh bidan yang merujuk ibu bersalin yang mengalami komplikasi di Rumah Sakit Singaparna Medika Citra Utama Periode Bulan Maret - April Tahun 2017 mayoritas bidan tidak melakukan penerapan kelengkapan rujukan yaitu 26 orang $(78,8 \%)$ yang kelengkaan rujukannya tidak sesuai dengan SOP dan sekitar 7 orang ( $21,2 \%$ ) yang kelengkapan rujukan sesuai dengan SOP.

\section{PEMBAHASAN}

Beberapa komplikasi pada persalinan yang mungkin terjadi dan memungkinkan untuk dilakukan rujukan dan penanganan pra rujukannya menurut JNPK-KR (2008) adalah gawat janin, ketuban pecah dini, inersia uteri, ketuban bercampur meconium, persalinan lama dan retensio plasenta. Dalam penelitian ini ditemukan komplikasi terbanyak adalah pada inersia uteri $(57,58 \%)$. Inertia uteri adalah kondisi kekuatan kontraksi yang tidak adekuat untuk melakukan
Tabel 5.5

Distribusi frekuensi kelengkapan rujukan pada ibu bersalin yang mengalami komplikasi di Rumah Sakit Singaparna Medika Citra Utama Periode Bulan Maret - April Tahun 2017

\begin{tabular}{lcc}
\hline Variabel & Jumlah & $\begin{array}{l}\text { Persentse } \\
(\%)\end{array}$ \\
\hline $\begin{array}{l}\text { Lengkap } \\
\text { sesuai } \\
\text { dengan }\end{array}$ & 7 & 21,2 \\
SOP & & \\
\hline $\begin{array}{l}\text { Tidak } \\
\text { Lengkap } \\
\text { sesuai dengan } \\
\text { SOP }\end{array}$ & 26 & 78,8 \\
\multicolumn{1}{c}{ Jumlah } & \\
\hline
\end{tabular}

pembukaan serviks atau mendorong janian keluar. Komplikasi yang akan terjadi dari kondisi ini adalah terjadinya partus lama yang tentunya kan berdampak tidak pada ibu bersalin, seringkali terjadi infeksi, kehabisan tenaga, dehidrasi, dll. Penanganan yang tepat apabila terjadi kondisi tersebut adalah lakukan rujukan dengan penatalaksanaan sesuai dengan prosedur.

Berdasarkan penelitian yang dilakukan mengenai gambaran penanganan pra rujukan pada ibu bersalin yang mengalami komplikasi oleh bidan didapatkan bahwa mayoritas bidan melakukan penanganan pra rujukan pada ibu bersalin sesuai dengan SOP yang ditentukan. Dimana dari 33 bidan yang melakukan rujukan $20(60,6 \%)$ responden yang melakukan penanganan pra rujukan sesuai dengan SOP. Penanganana pra rujukan merupkan hal yang harus dilakukan oleh bidan dalam upaya stabilisasi pasien sebelum dilakukan rujukan. Hal ini sesuai dengan 
kewenangan bidan dalan tatalaksana kasus ibu bersalin yang mengalami penyulit.

Hasil penelitian ini pun memberikan gambaran mayoritas bidan tidak melakukan penerapan kelengkapan rujukan sesuai dengan SOP yang telah ditentukan,. Responden yang tidak melakukan penerapan kelengkapan rujukan sesuai dengan SOP yaitu sebanyak 26 responden (78,8\%). Kelengkapan rujukan ini salah satunya dalah partograf. Sebagain besar bidan tidak membawa partograf pada saat melakukan rujukan. Sebagian besar komplikasi yang dirujuk pada penelitian ini adalah insetia uteri, hal ini tentunya dapat terdeteksi dari pemantauan persalinan dengan menggunakan partograf. Partograf merupakan alat pemantauan kemajuan persalianan yang salah satu fungsinya dalah untuk pengambilan keputusan klinis pada saat pertolongan persalinan. Bidan dapat membuat keutusan yang tepat apabila dalam pertolongan persalinan melakukan pemantauan dengan menggunakan partograf.

\section{KESIMPULAN}

Sebagian besar komplikasi rujukan adalah inersia uteri 29 orang (57.58\%). Mayoritas melakukan penanganan pra rujukan sesuai dengan prosedur yang telah ditetapkan yaitu sebanyak 20 responden $(60,60 \%)$. Sebagian kecil sebanyak 7 responden yang melakukan penerapan kelengkapan rujukan sesuai dengan SOP $(21,21 \%)$

Sebagai bidan harus terus meningkatkan kemampuan dalam melakukan penanganan pra rujukan pada kasus ibu bersalin, dan harus memenuhi kelengkapan rujukan, dalam hal ini patuh terhadap penggunaan partograf pada saat pemantauan persalinan.

Adanya kebijakan bagi rumah sakit untuk memberlakukan standar penerimaan rujukan ibu bersalin dan meningkatkan kompetensi bidan yang bertugas di rumah sakit Singaparna Medika Citra Utama, sehingga ibu 91 bersalin yang dirujuk harus ditangani terlebih dahulu sesuai dengan standar yang telah ditetapkan.

Diharapkan dengan adanya penelitian ini dinas kesehatan bisa membantu permasalahan bidan mengenai penanganan dan penerapan kelengkapan rujukan yang belum sesuai dengan standar khususnya dalam penggunaan partograf pada saat persalinan.

\section{E. DAFTAR PUSTAKA}

Badriah, Dewi dkk. 2012. Asuhan Persalinan Bagi Bidan, Penerbit PT Refika Aditama, Bandung, Hal 5-24

JNPKR-KR, 2008. Asuhan Persalinan

Normal. JNPK-KR-Depkes

JNPKR-KR, 2013. Asuhan Persalinan

Normal. JNPK-KR-Depkes

Kementrian Kesehatan Republik

Indonesia tahun 2010

Kementrian Kesehatan Republik

Indonesia Tahun 2016

Keputusan Mentri Kesehatan

RepublicIndonesia Nomor

369/MENKES/SK/111/2007

Lisnawati Lilis, 2013. Asuhan Kebidanan Terkini Kegawat Daruratan Maternal Neonatal. Cv Trans Info Medika, Jakarta Timur:

Peraturan Mentri Kesehatan Republik Indonesia Nomor

1464/MENKES/PER/X/2010

Prawirohardjo, Sarwono. 2013. Ilmu Kebidanan, PT Bina Puataka Sarwono

Prawihardjo, Jakarta, Hal 315-329

Profil Kesehatan Jawa Barat Tahun 2012

Purwoastuti, Endang dkk. 2014. Asuhan Kebidanan Persalinan\& Bayi Baru Lahir, PT Pustaka Baru, Yogyakarta, Hal 67

Purwoastuti, Endang dkk. 2014. Konsep Kebidanan, PT Puustaka Baru, yogyakarta, Hal:1-2, 87-98 
Yantina, Yuli. 2016. Asuhan kebidanan persalinan., Bina Pura Aksara, Tangerang Selatan, hal; 8 